\title{
Galectin-1 as a predictive biomarker in ovarian cancer
}

\author{
Mahak Masoodi ${ }^{1}$, Zafar A. Shah ${ }^{1 *}$, Afaq H. Beigh'1, Sheikh Zahoor Ahmad², Abdul Wahid Mir², Besina Yasin ${ }^{3}$, \\ Roohi Rasool ${ }^{1}$, Khalid Z. Masoodi and Gull Mohammad Bhat ${ }^{5}$
}

\begin{abstract}
Aim: There is an urgent need to set up a useful biomarker for ovarian cancer. Galectin-1 is a promising carbohydratebinding protein which plays a remarkable role in various malignancies yet its clinical significance is questionable. In this study, we have tested the clinical implications of serum Galectin-1 levels in patients with ovarian tumours.

Main methods: Serum Galectin-1 levels were quantified in 84 newly diagnosed ovarian tumour patients and 20 healthy controls by Enzyme Linked Immuno Sorbent Assay during the course of the disease. Therefore the samples were taken at diagnosis, after surgery and after chemotherapy.

Key findings: The Galectin-1 levels were found to be associated with various variables of Ovarian Cancer patients. The levels were found to be prominently high in postmenopausal patients. Galectin-1 levels were raised in epithelial ovarian tumours with significantly high levels in serous subtype. A decrease in Galectin-1 levels post-surgical intervention and after receiving chemotherapy was found. Galectin-1 levels evidently distinguished between normal, benign, malignant and metastatic cases as compared to CA125 levels. Galectin-1 demonstrated to be a better biomarker than CA125 according to the Receiver Operating Characteristic (ROC) curve analysis.

Significance: The study emphasizes that serum Galectin-1 may serve as a better surrogate biomarker in Ovarian Cancer for early detection, discriminating between malignant and benign abdominal masses and monitoring the progression of the disease and response to treatment.
\end{abstract}

Keywords: Galectin-1, Ovarian Cancer, CA125, Biomarker, ELISA

\section{Introduction}

Ovarian carcinoma is a lethal gynaecological cancer with distinguishing biology at the molecular, cellular and clinical level $[1,2]$. It is the eighth most common cause of death worldwide killing 140,000 women [3]. It has the worst prognosis and high mortality rate owing to the lack of proper screening, poor diagnosis and late detection of the disease, therefore termed a "silent killer" [4]. Epithelial ovarian tumours are most common, comprising of about $90 \%$ of ovarian tumours and are further

*Correspondence: zaffaramin@gmail.com

${ }^{1}$ Department of Immunology and Molecular Medicine, Sher-e-Kashmir Institute of Medical Sciences, Srinagar, Jammu and Kashmir, India

Full list of author information is available at the end of the article categorized as: serous, mucinous, endometrioid and clear cell carcinomas [5]. Most of the women diagnosed at later stages have a 05 years survival rate of only $46 \%$ after getting standard treatment [6]. Initial treatment criteria for ovarian cancer include primary de-bulking surgery followed by paclitaxel/cisplatin adjuvant chemotherapy or neo-adjuvant chemotherapy (NACT) plus interval surgical cyto-reduction and adjuvant chemotherapy [7]. Cancer Antigen 125 (CA-125) is a useful biomarker for monitoring the progression of the disease yet lacks sensitivity as well as specificity as it increases in benign conditions like ovarian cysts, uterine fibroids and infections [8]. Thus there is a requirement for the identification of novel biomarkers for the screening of the disease.

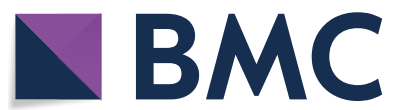

(c) The Author(s) 2021. Open Access This article is licensed under a Creative Commons Attribution 4.0 International License, which permits use, sharing, adaptation, distribution and reproduction in any medium or format, as long as you give appropriate credit to the original author(s) and the source, provide a link to the Creative Commons licence, and indicate if changes were made. The images or other third party material in this article are included in the article's Creative Commons licence, unless indicated otherwise in a credit line to the material. If material is not included in the article's Creative Commons licence and your intended use is not permitted by statutory regulation or exceeds the permitted use, you will need to obtain permission directly from the copyright holder. To view a copy of this licence, visit http://creativecommons.org/licenses/by/4.0/. The Creative Commons Public Domain Dedication waiver (http://creativeco mmons.org/publicdomain/zero/1.0/) applies to the data made available in this article, unless otherwise stated in a credit line to the data. 
There has been a breakthrough in the field of oncology with the discovery of galectins and since then they have taken a centre stage in cancer research due to their aberrant expression and immunosuppression in the tumours [9]. They are small molecular weight, soluble, glycanbinding proteins [10] that are implicated in regulating cell growth, cell adhesion, apoptosis, development and progression of tumours. In mammals, there are 15 members in the Galectin family out of which 13 have been identified as key proteins in the oncogenesis of different human cancer [11]. Galectin-1 is a prototype Galectin; first protein discovered in Galectin family [12]. It is a $14 \mathrm{KDa} \beta$ galactoside binding protein which participates in various biological functions like tissue development, cell proliferation, pre mRNA splicing and immunoregulation [13]. It is a homodimerizing pleiotropic protein whose function is dependent on its location as well as concentration. Galectin-1 shows intracellular as well as extracellular functions and is found both inside as well as outside the cell. Intracellularly it binds with various other proteins in sugar independent manner and extracellularly it interacts in sugar dependent manner with $\beta$ galactoside glycol conjugates [14]. Galectin-1 has been detected in various malignancies like pancreatic cancer, hepatocellular cancer, prostate cancer, ovarian cancer and breast cancer. It is involved in various key processes of carcinogenesis like metastasis, angiogenesis and immunosuppression [15]. Serum Galectin-1 has been validated in various diseases like rheumatoid arthritis, high grade gliomas, neuroblastomas and head and neck squamous cell carcinomas as a potential biomarker and to monitor progression and response to treatment [16-19].

In this study we investigated serum levels of Galectin-1 in patients with ovarian tumours and its efficacy as a biomarker for diagnosis and monitoring progression and response to treatment.

\section{Material and methods}

This study comprised of 84 patients with newly diagnosed ovarian cancer and seeking treatment either cytoreduction surgery or conventional paclitaxel/carboplatin chemotherapy from Departments of Surgical and Medical Oncology respectively at Sheri-Kashmir Institute of Medical Sciences from April 2018 to May2020 (Fig. 1). Blood sample were collected from patients when diagnosed, after debulking surgery and post chemotherapy at different intervals. 20 healthy females were recruited as controls and samples were collected as desired. The study was approved by SKIMS IEC vide protocol no. 59/2018. Proper consent as required was taken from each patient and control enrolled in the study.

Blood samples were collected in a serum separator tube and allowed to clot at room temperature. The serum was separated by centrifugation, aliquoted and stored at $-80^{\circ} \mathrm{C}$ till further use. Serum Galectin-1 was measured using human Galectin-1 Picokine ${ }^{\text {TM }}$ ELISA kit from Boster Biological technology, USA according to the manufacturer's guidelines. Serum CA-125 levels were measured by chemiluminescence technique using Beckman coulter reagents.

\section{Statistical analysis}

Statistical analysis was performed by using Graph Pad Prism 5 software and all quantitative data were presented as mean \pm S.D. Student's t-test and one way ANOVA was used to analyze statistical significance between the variables studied. Correlation between Galectin-1 levels and CA-125 was determined by spearman's rank correlation analysis. Receiver operator characteristic (ROC) curve was used to establish the cut-off values for Galectin-1 and CA125 serum levels with maximum sensitivity and specificity. The area under the curve was used to analyze the diagnostic accuracy of Galectin-1 and CA-125. A $p$-value $<0.05$ was considered statistically significant.

\section{Results}

\section{Patient characteristics}

An outline of patient characteristics is given below in the Table $1.84 .5 \%$ of the patients were diagnosed with epithelial ovarian cancer mostly with serous histology (Fig. 1) and at an advanced disease stage.

\section{Galectin-1 levels in patient with ovarian tumours}

The serum levels of Galectin-1(40.57 $\pm 22.2 \mathrm{ng} / \mathrm{ml})$ in patients with newly diagnosed ovarian tumours $(n=84)$ were significantly higher than the levels $(9.19 \pm 4.61 \mathrm{ng} /$ $\mathrm{ml})(p<0.0001)$ in healthy controls $(n=20)$ (Fig. 2a). According to their menopausal status, in postmenopausal patients the Galectin-1 levels $(51.02 \pm 19.95 \mathrm{ng} / \mathrm{ml})$ were significantly higher than levels in premenopausal patients $(29.66 \pm 18.13 \mathrm{ng} / \mathrm{ml})(p<0.0021)$ (Fig. 2b). The Galectin 1 levels were analyzed further in patients categorized into the following groups:

a) Galectin 1 levels in patients with different Ovarian Tumour Histotypes:

Patients with epithelial ovarian tumours were significantly having high levels $(44.22 \pm 22.06 \mathrm{ng} / \mathrm{ml})$ than patients with germ cell ovarian tumours $(16.71 \pm 6.51$ $\mathrm{ng} / \mathrm{ml})(p<0.0162)$ (Fig. 3a), however, no significant difference was found in serum levels of Galectin-1 in patients with sex stromal tumours $(37.04 \pm 4.48 \mathrm{ng} /$ ml) $(p>0.05)$. Further, on comparing epithelial ovarian tumour subtypes with Galectin-1 levels, there was no significance found except between the patients 


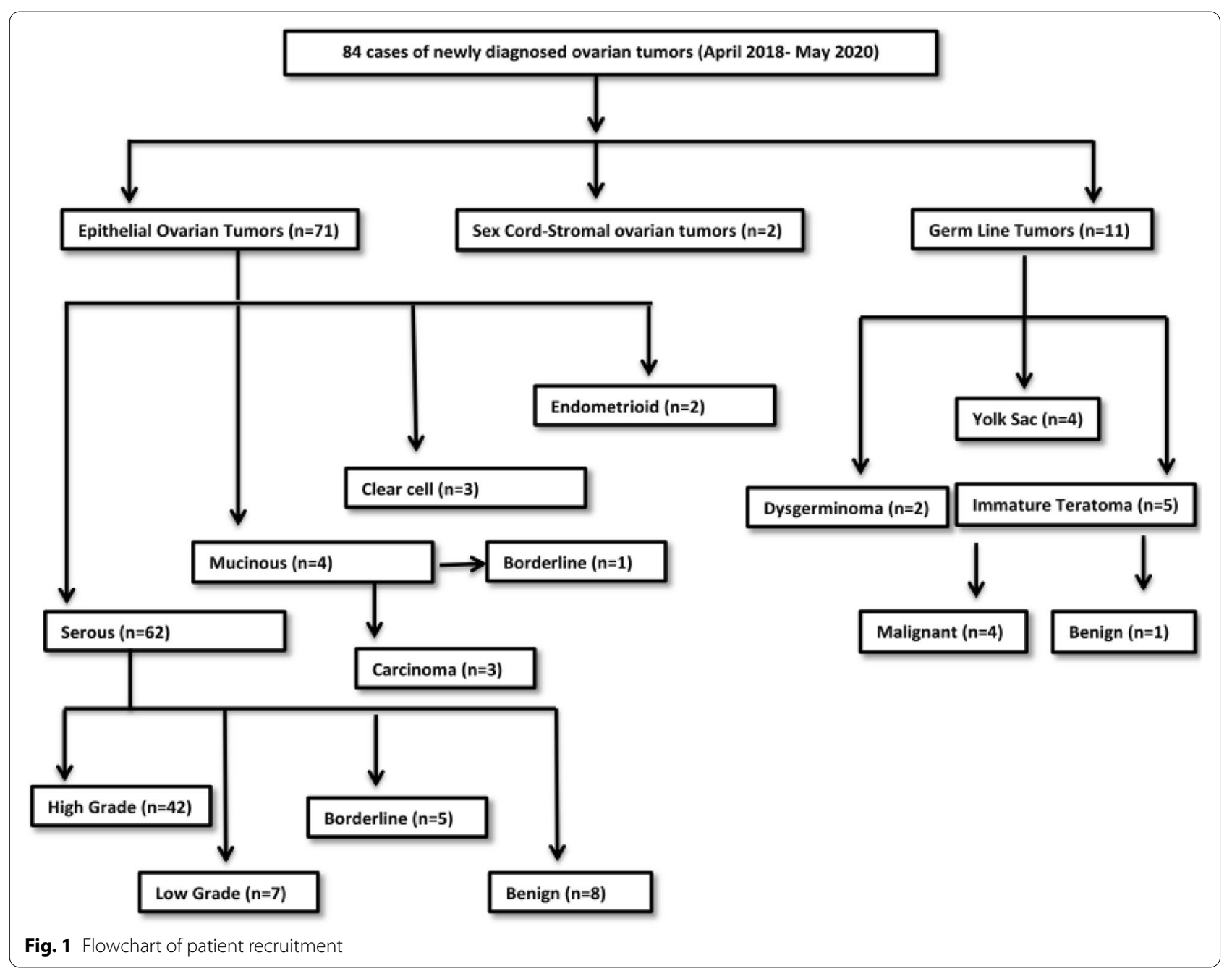

with serous epithelial ovarian tumours $(45.47 \pm 22.12$ $\mathrm{ng} / \mathrm{ml})$ and mucinous ovarian tumours (14.55 \pm 1.32 $\mathrm{ng} / \mathrm{ml})(p<0.0071)$ (Fig. 3b).

b) Galectin-1 levels in patients planned for primary debulking surgery

The Galectin- 1 levels in patients $(n=70)$ who were planned for primary debulking surgery $(44.20 \pm 21.45$ $\mathrm{ng} / \mathrm{ml}$ ) showed a significant decrease in Galectin-1 levels post-surgery $(19.50 \pm 9.03 \mathrm{ng} / \mathrm{ml})(p<0.0002)$. Out of 70 patients, 26 patients received 6 cycles of adjuvant paclitaxel carboplatin chemotherapy rest of the patients were having benign/borderline disease or were in the early stages of the disease, 2 patients died after surgery and hence were excluded from the study. After 6 cycles of adjuvant chemotherapy a significant decrease in Galectin-1 levels (23.29 $\pm 9.98 \mathrm{ng} /$ $\mathrm{ml}$ ) was observed in patients than the levels pre-surgery $(p<0.05)$ (Fig. 4a). A non-significant increase in Galectin-1 levels was observed in these patients after receiving chemotherapy ( $\mathrm{p}>0.05)$ as compared to levels after surgery.

c) Galectin-1 levels in patients planned for NACT (Neo Adjuvant Chemotherapy)

The patients $(n=14)$ who were planned for NACT $(45.83 \pm 15.31 \mathrm{ng} / \mathrm{ml})$ received 6 cycles of chemotherapy and showed a significant decrease in the Galectin-1 levels post $6^{\text {th }}$ cycle $(18.8 \pm 6.42 \mathrm{ng} / \mathrm{ml})$ $(p<0.0137)$ (Fig. 4b).

The Galectin-1 levels of patients $(n$ 6) who were scheduled for first 3 cycles of NACT and then interval cytoreduction $(45.83 \pm 15.31 \mathrm{ng} / \mathrm{ml})$, showed a significant decrease in Galectin-1 levels post interval cytoreduction $(16.7 \pm 1.43 \mathrm{ng} / \mathrm{ml})(p<0.05)$ as well as after receiving 3 more cycles $(12.15 \pm 0.72 \mathrm{ng} / \mathrm{ml})$ $(p=0.0017)$ (Fig. 4c). 
Table 1 Clinico- pathological characteristics of patients with ovarian tumours

\begin{tabular}{|c|c|c|}
\hline \multirow[t]{2}{*}{ Characteristics } & \multicolumn{2}{|l|}{$N=84$} \\
\hline & No of patients & \%age \\
\hline \multicolumn{3}{|l|}{ Age (years) } \\
\hline Mean age & & $46.66 \pm 15.42$ \\
\hline Median & & 50 \\
\hline Range & & $14-70$ \\
\hline$>45$ & 48 & 57.1 \\
\hline$\leq 45$ & 36 & 42.8 \\
\hline \multicolumn{3}{|l|}{ Menopause } \\
\hline $\begin{array}{l}\text { Pre } \\
\text { Post }\end{array}$ & $\begin{array}{l}35 \\
49\end{array}$ & $\begin{array}{l}41.6 \\
58.3\end{array}$ \\
\hline \multicolumn{3}{|l|}{ FIGO Stage } \\
\hline $\begin{array}{l}|-| \mid \\
\text { III-IV }\end{array}$ & $\begin{array}{l}27 \\
46\end{array}$ & $\begin{array}{l}32.1 \\
54.7\end{array}$ \\
\hline \multicolumn{3}{|c|}{ Lymph nodes involved } \\
\hline $\begin{array}{l}\text { Yes } \\
\text { No }\end{array}$ & $\begin{array}{l}28 \\
56\end{array}$ & $\begin{array}{l}33.3 \\
66.6\end{array}$ \\
\hline \multicolumn{3}{|l|}{ Metastasis } \\
\hline $\begin{array}{l}\text { No } \\
\text { Yes }\end{array}$ & $\begin{array}{l}41 \\
43\end{array}$ & $\begin{array}{l}48.8 \\
51.1\end{array}$ \\
\hline \multicolumn{3}{|l|}{ Parity } \\
\hline $\begin{array}{l}0 \\
>1\end{array}$ & $\begin{array}{l}20 \\
64\end{array}$ & $\begin{array}{l}23.8 \\
76.1\end{array}$ \\
\hline \multicolumn{3}{|l|}{ Menstruation } \\
\hline $\begin{array}{l}\text { Normal } \\
\text { Amenorrhea } \\
\text { Dysmenorrhea } \\
\text { Polymenorrhea }\end{array}$ & $\begin{array}{l}50 \\
4 \\
28 \\
2\end{array}$ & $\begin{array}{l}59.5 \\
4.7 \\
33.3 \\
2.3\end{array}$ \\
\hline
\end{tabular}

\section{Association of Galectin-1 and CA-125}

Serum Galectin-1 levels from naïve patients positively correlated with their serum CA-125 levels $(n=84$, $r=0.558, p<0.0001$ ) (Fig. 5). Galectin-1 levels and CA-125 levels were analyzed in different patient groups as:

a) Ovarian tumour type: Galectin-1 levels in serum of patients with malignant ovarian tumours $(45.35 \pm 19.88$ $\mathrm{ng} / \mathrm{ml}$ ) were found to be higher significantly as compared to the controls $(9.1 \pm 4.6 \mathrm{ng} / \mathrm{ml})$ and benign ovarian tumours $(10.0 \pm 5.29 \mathrm{ng} / \mathrm{ml})(p<0.0001)$ (Fig. 6a). CA-125 levels were significantly higher in patients with malignancy $(472.3 \pm 544.5 \mathrm{U} / \mathrm{ml})$ as compared to healthy controls $(24.13 \pm 9.6 \mathrm{U} / \mathrm{ml})(p=0.0026)$ but there was no significant difference found between patients with malignant tumours and benign tumours ( $p>0.05$ ) (Fig. 6b).

b) FIGO Stage: Serum Galectin-1 levels were significantly lower in controls $(9.1 \pm 4.6 \mathrm{ng} / \mathrm{ml})$ as compared to early stage patients $(35.6 \pm 21.8 \mathrm{ng} / \mathrm{ml})(p=0.001)$ as well as late stage patients $(52.22 \pm 20.18 \mathrm{ng} / \mathrm{ml})(p=0.001)$. A significant different in Galectin-1 levels was also observed between initial stages and later stages $(p<0.05)$ (Fig. 7a). There was no significance in CA-125 levels at various stages of malignancy but a significant difference was found between higher stages $(672 \pm 597.3 \mathrm{U} / \mathrm{ml})$ and controls $(24.13 \pm 9.6 \mathrm{U} / \mathrm{ml}))(p=0.0365)$ (Fig. 7b).

c) Lymph Node Involved and Metastasis: Galectin-1 levels were significantly high in patients with lymph node involvement $(53.6 \pm 20.18 \mathrm{ng} / \mathrm{ml})$ than patients without lymph node involvement $(34.33 \pm 22.53 \mathrm{ng} / \mathrm{ml})$ $(p=0.0021)$ (Fig. 8a). The CA-125 exhibited no significance between patients with and without lymph nodes involved ( $p>0.05)$ (Fig. 8b). Similarly Galectin-1 levels in patients with metastasis $(52.3 \pm 19.75 \mathrm{ng} / \mathrm{ml})$ were high than patients without metastasis $(39.88 \pm 19.88 \mathrm{ng} / \mathrm{ml})(p$ $=0.0001$ ) (Fig. 8c). CA125 levels displayed no such significance between metastatic and non-metastatic patients (Fig. 8d).
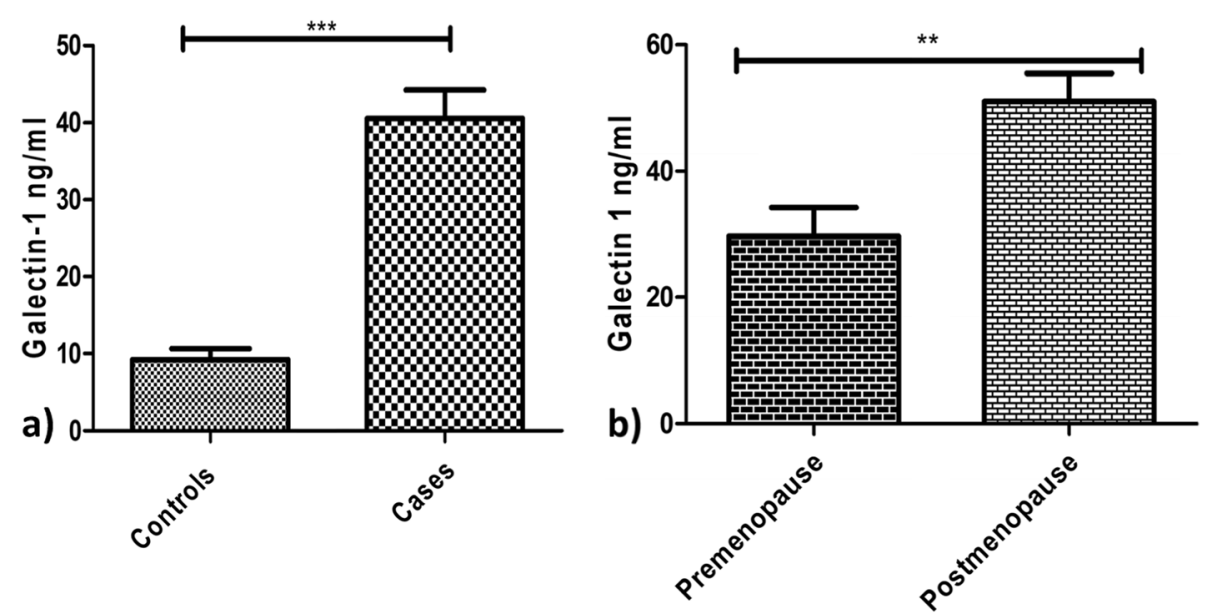

Fig. 2 Serum Galectin -1 levels in a) healthy controls vs patients with Ovarian Tumours. b) Premenopausal patients vs postmenopausal patients 

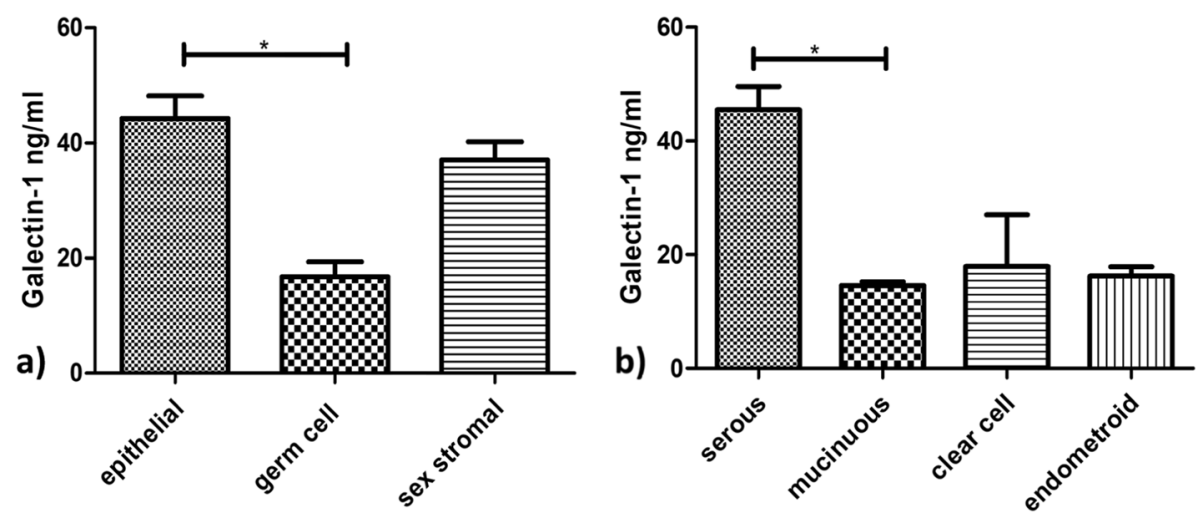

Fig. 3 a) Serum Galectin-1 levels in ovarian tumour histotypes b) epithelial ovarian tumour subtypes
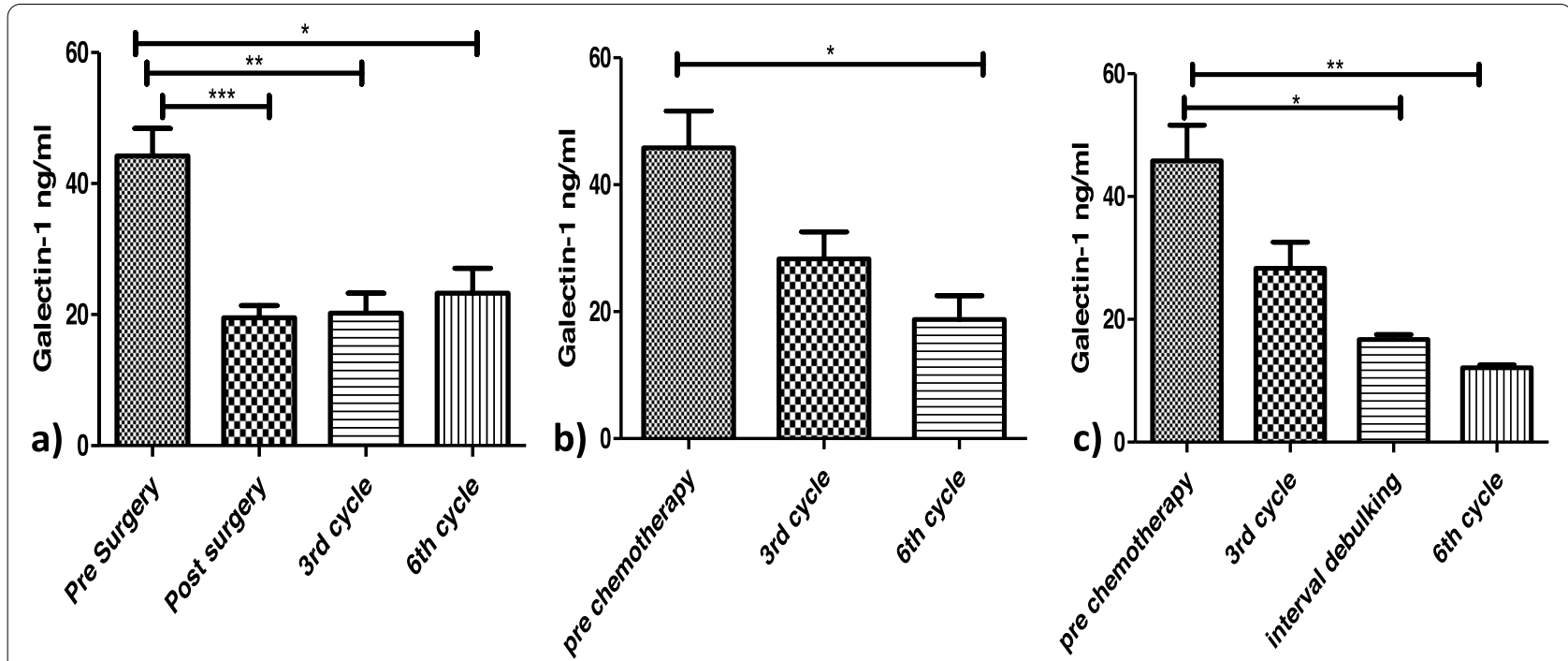

Fig. 4 Serum Galectin -1 levels in OC patients (a) before and after surgery and adjuvant chemotherapy, (b) post neo adjuvant chemotherapy, (c) post NACT followed by interval cytoreduction and adjuvant chemotherapy

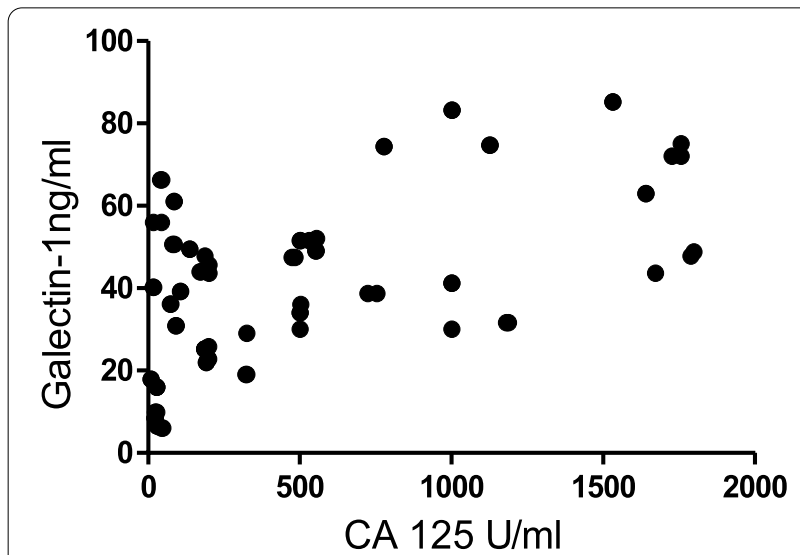

Fig. 5 Correlation between Serum Galectin -1 levels with serum CA-125 levels in patients with Ovarian Tumours
ROC curve analysis of serum Galectin-1 and CA-125

ROC curve analysis revealed an AUC of 0.936 (95\% CI 0.8681 to 1.004$)(p<0.0001)$ (Fig. 9a) for Galectin-1 and AUC of 0.89 (95\% CI 0.7960 to 0.9911$)(p<0.0002)$ (Fig. 9b) for CA-125. The cut off value of $>15.9 \mathrm{ng} / \mathrm{ml}$ for serum Galectin-1 for the diagnosis of ovarian carcinoma has $88.89 \%$ sensitivity and $93 \%$ specificity whereas, for CA- 125 cut off value of $>36.5 \mathrm{ng} / \mathrm{ml}$ has $80.65 \%$ sensitivity and $89 \%$ specificity Fig. 9.

\section{Discussion}

Ovarian cancers are aggressive as they can progress from early stages to advanced stages within a year. The disease could have been curable if detected at early stages but remains undetected till advanced stages due 

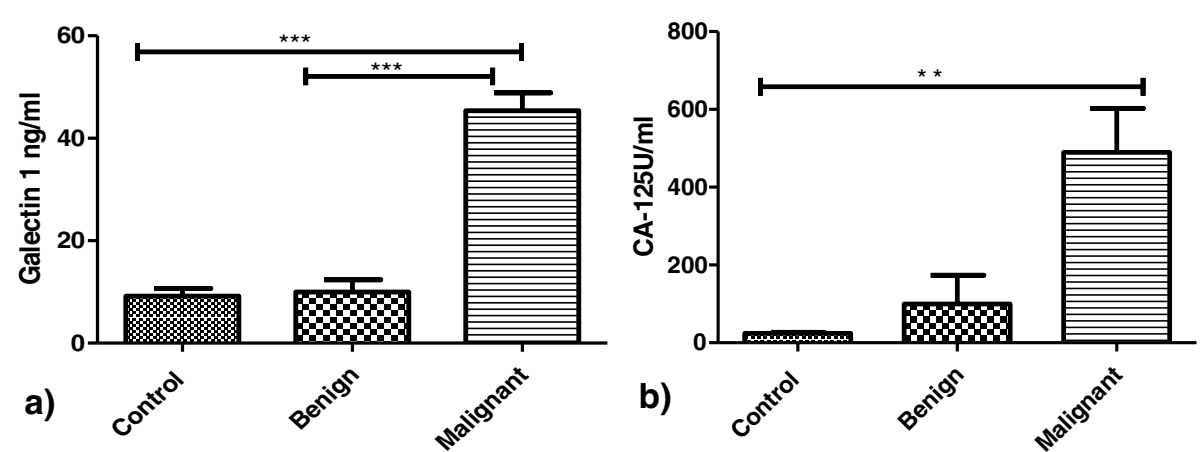

Fig. 6 a Serum Gal-1 levels in controls vs benign vs malignant cases. b Serum CA-125 levels in controls vs benign vs malignant cases
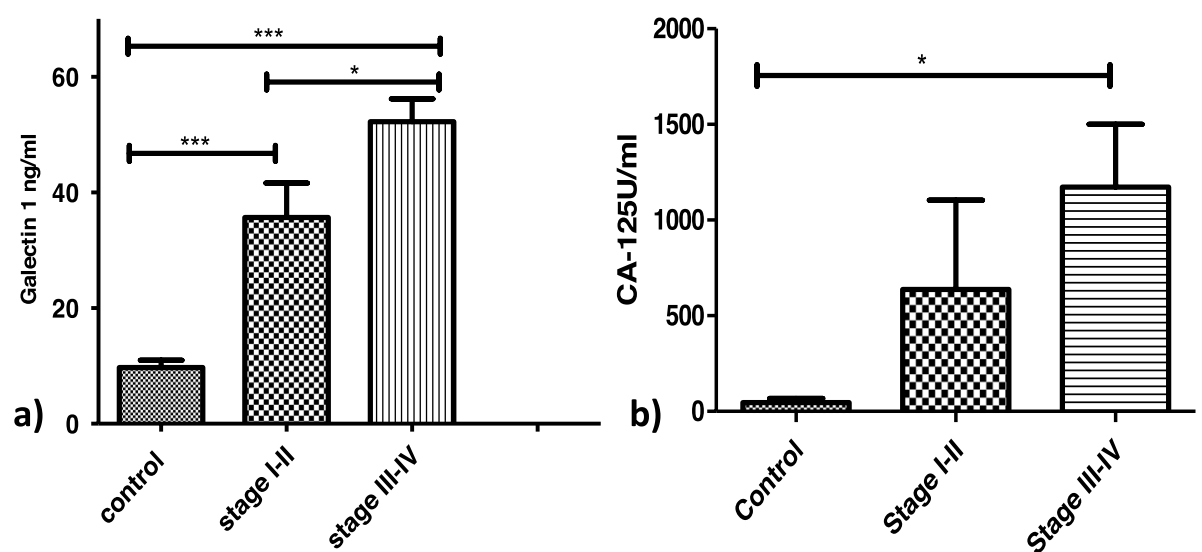

Fig. 7 Serum levels of $\mathbf{a}$ Galectin -1 and $\mathbf{b}$ CA-125 levels in OC patients with different FIGO stages

to its late presentation [20]. Moreover the lack of effective screening and reliable biomarker has led to its high fatality [21]. CA-125 is currently used as biomarker for ovarian cancer but its specificity and sensitivity is limited. So far few serum markers like HE-4 have been evaluated but their efficacy as biomarkers for ovarian carcinomas still remains elusive [22, 23]. So in search of a better biomarker we have evaluated the levels of Galectin-1 in serum samples of patients diagnosed with ovarian tumors. Galectin-1 levels were higher in the serum of patients as compared to the healthy controls and same was reported by M. M. Abdel wahab et al. [24] and Chen et al. [25]. It is well know that menopausal status is a risk factor for ovarian cancer [26]. In our study it has been reported for the first time that postmenopausal women with ovarian tumours tend to have higher levels of serum Galectin-1 than premenopausal patients. In contrast Chen et al. [25] found no significance between serum Galectin-1 levels and menopausal status. Thus our study proposes high levels of galectin1 in postmenopausal women are an indication of a poor oncological outcome. Galectin-1 levels were high significantly in epithelial tumours as compared to germ cell tumours unlike Chen et al. who didn't find any significant difference between various histologies of OC [25]. Galectin-1 levels were significantly high in serous tumours as reported by Chen et al. [25], Labrie et al. [27] and M. M. Abdelwahab et al. [24] than mucinous subtype as reported by Chen et al. [25] and histologically confirmed by Chetry et al [28]. According to the treatment paradigms, the naïve OC patients who were planned for primary debulking surgery showed a quite significant decrease in Galectinllevels post debulking surgery which infers high serum levels of Galectin-1 are produced and secreted in serum by tumor and its tumor associated stroma [15]. Similar findings were reported by Chen et al [25] also but their sample size was small (10 patients) on the other hand our study was carried out on 57 patients (Fig. 1). After receiving 3 or 6 cycles of adjuvant chemotherapy a significant decrease was observed in Galectin-1 levels than the levels pre surgery. OC patients often show a high responsiveness to cisplatin chemotherapies at first but eventually develop platinum resistance. It has been reported that Galectin-1contributes to cisplatin resistance in EOC cells 


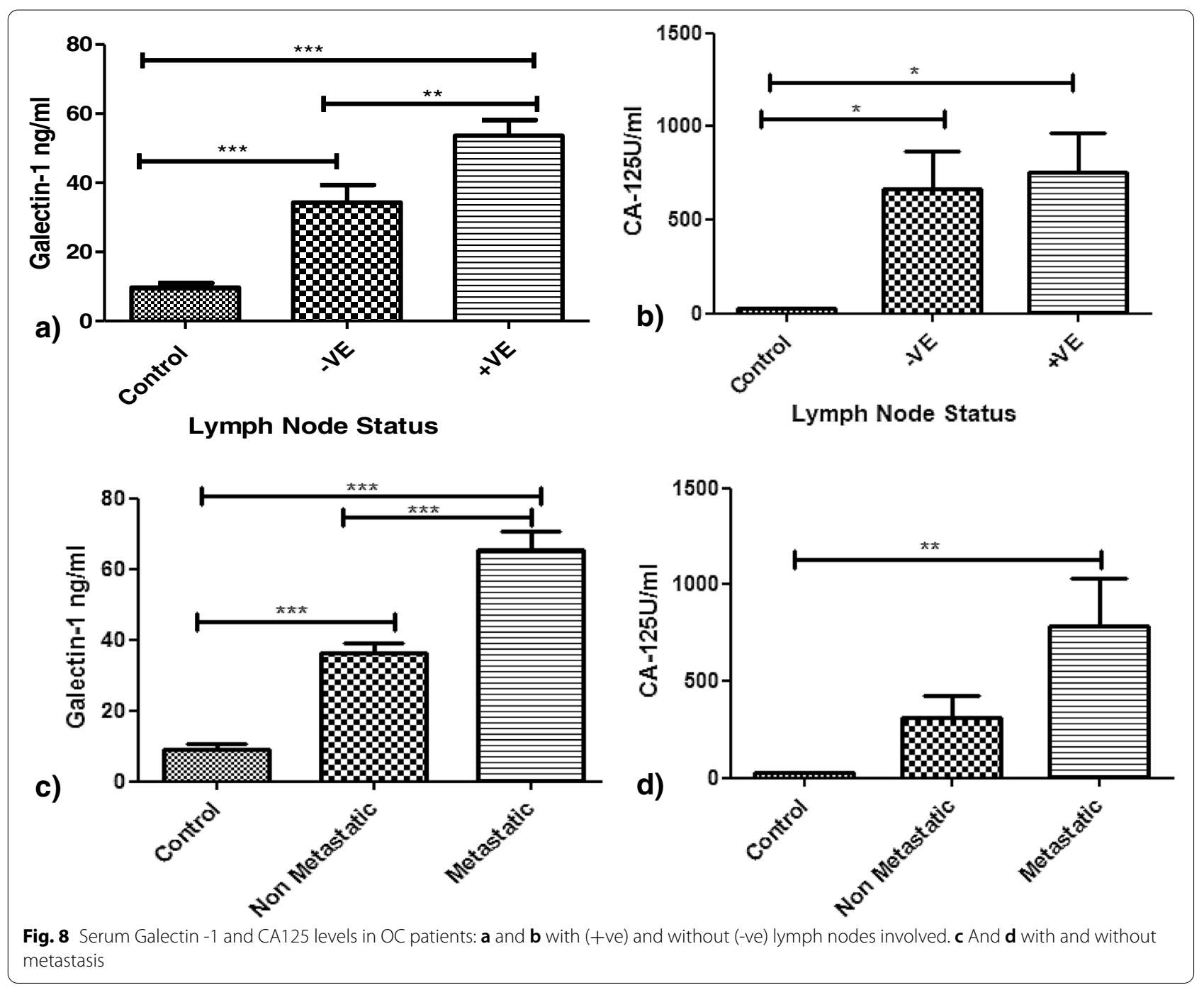

Fig. 8 Serum Galectin -1 and CA125 levels in OC patients: a and $\mathbf{b}$ with (+ve) and without (-ve) lymph nodes involved. $\mathbf{c}$ And $\mathbf{d}$ with and without metastasis
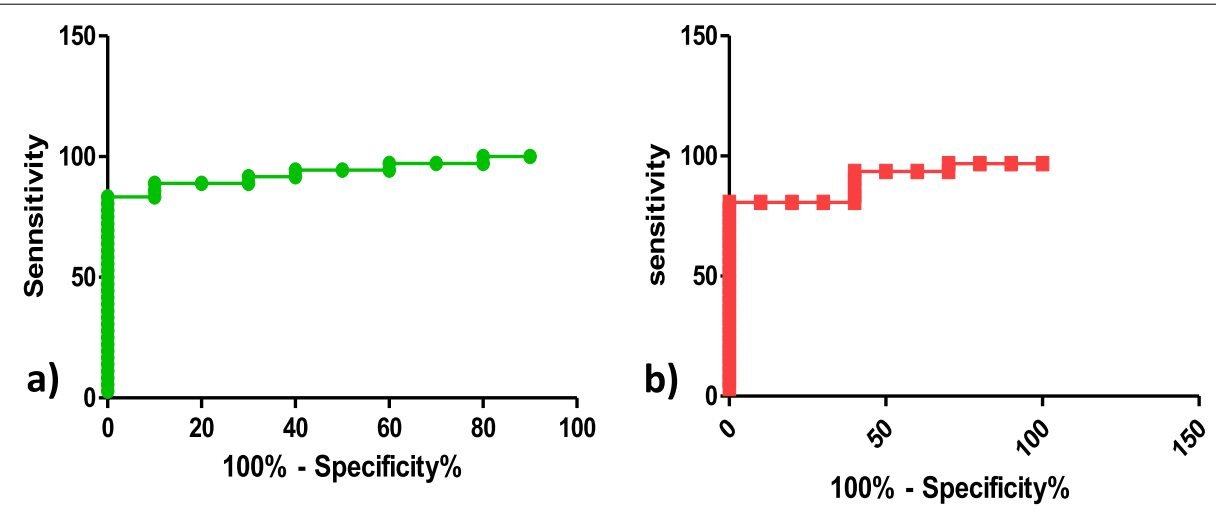

Fig. 9 ROC curves depicting specificity and sensitivity of a Serum Gal-1 with AUC of 0.936 and $\mathbf{b}$ serum CA- 125 with AUC of 0.89 to distinguish between controls and OC patients 
[13]. In our study, there was an increase in Galectin-1 levels with increasing cycles of chemotherapy but the results were insignificant. Thus there is a need to follow such patients for more cycles to corroborate these findings in developing chemo resistance. However, our study is the first to report Galectin-1 levels after more than 3 cycles of adjuvant chemotherapy. The group of patients who received NACT (NeoAdjuvant Chemotherapy) showed a significant decrease in Galectin-1 serum levels post $3^{\text {rd }}$ and $6^{\text {th }}$ cycles in contrast Coosmans et al [29] reported an increase in Galectin 1 levels post 3 cycle of chemotherapy. The patients who received 3 cycles of NACT followed by interval cytoreduction and then 3 cycles of adjuvant chemotherapy exhibited a significant decrease in serum Galectin-1 after interval cytoreduction and after $6^{\text {th }}$ cycle. This finding is being reported for the first time in such patients.

As CA-125 is used commonly as a biomarker for OC therefore we investigated its relationship with Galectin-1 serum levels and found a strong correlation between the two as was reported by Chen et al. [25] and M. M. Abdelwahab et al. [24]. In our study, Serum Galectin-1 levels were able to discriminate between benign and malignant tumours than serum CA-125 levels on contrary Chen et al. stated otherwise. The serum Galectin-1 levels differentiated between early and advanced stages of malignancy as reported by Chen et al. [25] and Abdelwahab et al. [24] and has been confirmed by functional studies by P Zhang et al. [13] whereas serum CA-125 levels could only differentiate advanced stage patients from healthy controls. Thus, supporting our hypothesis that unlike CA125, Galectin-1 correlates with clinical stage and can be helpful for the early detection of the disease. The serum Galectin-1 levels were distinguishable between the patients with and without lymph nodes involved but CA-125 levels couldn't make such distinction. This has been another finding of our study. In our study OC patients with localized disease had low Galectin-1 levels as compared to patients with metastasis which are in tune with reports by Chen et al. [25] and Abdel wahab et al. [24]. On ROC curve analysis, Galectin-1 has a greater discriminative ability than CA-125 between $\mathrm{OC}$ patients and healthy controls with Galectin1levels to be more sensitive and specific than CA-125 levels as was also reported by Abdelwahab et al. [24] and Labrie et al. [27].

\section{Conclusion}

The study highlights the clinical significance of serum Galectin-1 as a suitable noninvasive biomarker for the early detection of the OC, monitoring response to treatment and an indicator of tumour metastasis and invasion.
Acknowledgments

Not applicable

Code availability

Not Applicable

\section{Authors' contributions}

ZAS and MM contributed to the design of the work. RR and ZAS gave final approval of this version to be published. MM and AHB performed all the experiments. ZAS, SZA, AWM, BY, RR and MM contributed to the data analysis. MM, AHB, KZM and GMB tested the statistical methods. All authors read and approved the final manuscript.

Funding

The study was funded by SKIMS under grant number PhD Immuno 45/16

Availability of data and materials

Contact Author for Data requests

\section{Declarations}

\section{Ethics approval and consent to participate}

The Study was approved by institutional ethical Committee SKIMS. Patient consent was taken before enrolling them in the Study

\section{Consent for publication}

Not Applicable

\section{Competing interests}

All Authors declare no competing interests.

\section{Author details}

${ }^{1}$ Department of Immunology and Molecular Medicine, Sher-e-Kashmir Institute of Medical Sciences, Srinagar, Jammu and Kashmir, India. ${ }^{2}$ Department of Surgical Oncology, Sher-e-Kashmir Institute of Medical Sciences, Srinagar, Jammu and Kashmir, India. ${ }^{3}$ Department of Pathology, Sher-e-Kashmir Institute of Medical Sciences, Srinagar, Jammu and Kashmir, India. ${ }^{4}$ Division of Plant Biotechnology, Sher-e-Kashmir University of Agricultural Sciences and Technology, Srinagar, Jammu and Kashmir, India. ${ }^{5}$ Department of Medical Oncology, Sher-e-Kashmir Institute of Medical Sciences, Srinagar, Jammu and Kashmir, India.

Received: 17 March 2021 Accepted: 31 August 2021

Published online: 23 September 2021

\section{References}

1. Matulonis UA, Sood AK, Fallowfield L, Howitt BE, Sehouli J, Karlan BY. Ovarian cancer. Nat Rev Dis Prim. 2016;2:1-22. https://doi.org/10.1038/ nrdp.2016.61.

2. Kaldawy A, Segev Y, Lavie O, Auslender R, Sopik V, Narod SA. Gynecologic + oncology low-grade serous ovarian cancer: A review. Gynecol Oncol. 2016;143(2):433-8. https://doi.org/10.1016/j.ygyno.2016.08.320.

3. Mahmood RD, Morgan RD, Edmondson RJ, Clamp AR, Jayson GC, Jayson GC. First-line management of advanced high-grade serous ovarian cancer. Curr Oncol Rep. 2020.

4. Bast RC, Hennessy B, Mills GB. The biology of ovarian cancer: New opportunities for translation. Nat Rev Cancer. 2009;9(6):415-28. https://doi.org/ $10.1038 /$ nrc2644

5. Lheureux S, Gourley C, Vergote I, Oza AM. Seminar epithelial ovarian cancer. Lancet. 2019;393(10177):1240-53. https://doi.org/10.1016/S01406736(18)32552-2.

6. Jones HM, et al. Atorvastatin exhibits anti-tumorigenic and antimetastatic effects in ovarian cancer in vitro. Am J Cancer Res. 2017:7(12):2478-90

7. May T, et al. Original study a comparison of survival outcomes in advanced serous ovarian cancer patients treated with primary debulking surgery versus neoadjuvant chemotherapy. Int J Gynecol Cancer. 2017;27(4):668-74. https://doi.org/10.1097/IGC.0000000000000946. 
8. Duffy MJ, Bonfrer JM, Kulpa J, Rustin GJ, Soletormos G, Torre GC, et al. CA125 in ovarian cancer: European Group on tumor markers guidelines for clinical use. Int J Gynecol Cancer.

9. Ebrahim AH, et al. Galectins in cancer: Carcinogenesis, diagnosis and therapy. Ann Transl Med. 2014;2(9):1-7. https://doi.org/10.3978/j.issn. 2305-5839.2014.09.12

10. Liu FT, Rabinovich GA. Galectins as modulators of tumour progression. Nat Rev Cancer. 2005;5(1):29-41. https://doi.org/10.1038/nrc1527.

11. Chou FC, Chen HY, Kuo CC, Sytwu HK. Role of galectins in tumors and in clinical immunotherapy. Int J Mol Sci. 2018;19(2). https://doi.org/10.3390/ ijms19020430.

12. Camby I. Galectin-1: a small protein with major functions. Glycobiology. 2006;16(11):137R-57R. https://doi.org/10.1093/glycob/cwl025.

13. Zhang P, et al. Galectin-1 overexpression promotes progression and chemoresistance to cisplatin in epithelial ovarian cancer. Cell Death Dis. 2014;5(1):1-8. https://doi.org/10.1038/cddis.2013.526.

14. Huang C-S, et al. Galectin-1 upregulates CXCR4 to promote tumor progression and poor outcome in kidney cancer. J Am Soc Nephrol. 2014;25(7):1486-95. https://doi.org/10.1681/ASN.2013070773.

15. Astorgues-Xerri L, et al. Unraveling galectin-1 as a novel therapeutic target for cancer. Cancer Treat Rev. 2014;40(2):307-19. https://doi.org/10. 1016/j.ctrv.2013.07.007

16. Triguero-Martínez A, et al. Validation of galectin-1 as potential diagnostic biomarker of early rheumatoid arthritis. Sci Rep. 2020;10(1):1-10. https:// doi.org/10.1038/s41598-020-74185-8.

17. Verschuere T, et al. Altered galectin-1 serum levels in patients diagnosed with high-grade glioma. J Neuro-Oncol. 2013;115(1):9-17. https://doi. org/10.1007/s11060-013-1201-8.

18. Chen K, Cai Y, Zhang M, Wu Z, Wu Y. Both serum and tissue Galectin-1 levels are associated with adverse clinical features in neuroblastoma. Pediatr Blood Cancer. 2018;65(9):1-7. https://doi.org/10.1002/pbc.27229.

19. Saussez $S$, et al. The determination of the levels of circulating galectin-1 and -3 in HNSCC patients could be used to monitor tumor progression and/or responses to therapy. Oral Oncol. 2008;44(1):86-93. https://doi. org/10.1016/j.oraloncology.2006.12.014.

20. Farley J, Ozbun LL, Birrer MJ. Genomic analysis of epithelial ovarian cancer. Cell Res. 2008;18(5):538-48. https://doi.org/10.1038/cr.2008.52.
21. Brüggmann D, Pulch K, Klingelhöfer D, Pearce CL, Groneberg DA. Ovarian cancer: Density equalizing mapping of the global research architecture. Int J Health Geogr. 2017;16(1):1-14. https://doi.org/10.1186/ s12942-016-0076-2.

22. Heliström I, et al. The HE4 (WFDC2) protein is a biomarker for ovarian carcinoma. Cancer Res. 2003;63(13):3695-700.

23. Saravanan R, Bharathselvi M, Babu AC, Biswas J, Sulochana KN. The 88 kDa Eales' protein in serum is a complex of haptoglobin, complement C3 and galectin-1 as identified by liquid chromatography coupled mass spectrometry. Proteomics Clin Appl. 2016:1-36. https://doi.org/10.1002/ prca.201600068.

24. Abdelwahab MM, Ebian HF, Ibrahim TR, Badr MS, Lashin ME, Yassin MA. Clinical significance of serum galectin-1 and its tissue immunohistochemical expression in serous ovarian carcinoma patients. Open J Obstetr Gynecol. 2019:937-53. https://doi.org/10.4236/ojog.2019.97091.

25. Chen $\mathrm{L}$, et al. Clinical implication of the serum galectin-1 expression in epithelial ovarian cancer patients. J Ovarian Res. 2015;8(1):1-11. https:// doi.org/10.1186/s13048-015-0206-7.

26. Trifanescu OG, Gales LN, Trifanescu RA, Anghel RM. Clinical prognostic factors in pre-and post-menopausal women with ovarian carcinoma. Acta Endocrinol. 2018;14(3):353-9. https://doi.org/10.4183/aeb.2018.353.

27. Labrie M, De Araujo LOF, Communal L, Mes-Masson A-M, St-Pierre Y. Tissue and plasma levels of galectins in patients with high grade serous ovarian carcinoma as new predictive biomarkers. Sci Rep. 2017;7(1):13244. https://doi.org/10.1038/s41598-017-13802-5.

28. Chetry $M$, et al. The role of galectins in tumor progression, treatment and prognosis of gynecological cancers. J Cancer. 2018;9(24):4742-55. https:// doi.org/10.7150/jca.23628.

29. Coosemans A, et al. Immunosuppressive parameters in serum of ovarian cancer patients change during the disease course. Oncoimmunology. 2016;5(4). https://doi.org/10.1080/2162402X.2015.1111505.

\section{Publisher's Note}

Springer Nature remains neutral with regard to jurisdictional claims in published maps and institutional affiliations.
Ready to submit your research? Choose BMC and benefit from:

- fast, convenient online submission

- thorough peer review by experienced researchers in your field

- rapid publication on acceptance

- support for research data, including large and complex data types

- gold Open Access which fosters wider collaboration and increased citations

- maximum visibility for your research: over $100 \mathrm{M}$ website views per year

At BMC, research is always in progress.

Learn more biomedcentral.com/submissions 